\title{
Haematological Profile of Pregnant Women Attending Antenatal Clinic in Bauchi, Nigeria
}

\author{
Abubakar Saidu Kadas', Kenneth Okwong Okon ${ }^{2 *}$, Calvin Chama1, Mohammed Alkali ${ }^{3}$, \\ Yusuf Bara Jibrin'3, Sulayman Tunde Balogun4, Mohammed Aminu Baffa1, \\ Lamaran Makama Dattijo1, Abubakar Shehu' ${ }^{1}$

\begin{abstract}
${ }^{1}$ Department of Obstetrics and Gyneacology, Abubakar Tafawa Balewa Teaching Hospital, Bauchi, Nigeria
${ }^{2}$ Department of Medical Microbiology, Federal Medical Centre, Makurdi, Nigeria

${ }^{3}$ Department of Internal Medicine, Abubakar Tafawa Balewa Teaching Hospital, Bauchi, Nigeria

${ }^{4}$ Department of Clinical Pharmacology and Therapeutics, College of Medical Sciences, University of Maiduguri, Maiduguri, Nigeria

Email: *Okonkenneth@gmail.com
\end{abstract}

How to cite this paper: Kadas, A.S., Okon, K.O., Chama, C., Alkali, M., Jibrin, Y.B., Balogun, S.T., Baffa, M.A., Dattijo, L.M. and Shehu, A. (2020) Haematological Profile of Pregnant Women Attending Antenatal Clinic in Bauchi, Nigeria. Open Journal of Obstetrics and Gynecology, 10, 1776-1787. https://doi.org/10.4236/ojog.2020.10120160

Received: January 27, 2020

Accepted: December 28, 2020

Published: December 31, 2020

Copyright $\odot 2020$ by author(s) and Scientific Research Publishing Inc. This work is licensed under the Creative Commons Attribution International License (CC BY 4.0).

http://creativecommons.org/licenses/by/4.0/

\begin{abstract}
Introduction: Haematological profile of pregnant women provides vital information on physiological changes in pregnancy progress, outcome and possible maternal-foetal complications. The study assessed the haematological profile of pregnant women attending the antenatal clinic. Methodology: The cross-sectional study was conducted at the antenatal clinic of Abubakar Tafawa Balewa Teaching Hospital, Bauchi between July and September 2018 among pregnant women attending the antenatal clinic. Study participant was recruited on voluntary basis and study questionnaire and informed consent administered. Blood samples are collected and analysed using System $\mathrm{x}$ haematology autoanalyser. Result: A total of 191 study participants comprised of 141 pregnant women at different trimester stages and 50 non-pregnant. Mean haematocrit, haemgloblin, white blood count and platelet count of $35.8 \pm 9.0$, $11.6 \pm 1.6,7.7 \pm 5.7$, and $234.0 \pm 74.6$ respectively. Significant difference was observed between pregnant and non-pregnant women in neutrophil (0.016), mixed (eosinophil, basophil and monocyte, 0.05 ), lymphocyte (0.000), platelets (0.002) and RDWSD (0.025). Comparing haematological profile with trimester stages, significant association was observed with white blood cells count and mixed cell counts. Conclusion: The reduction in mean white blood cells count and increased haemocrit concentration with the trimester stages contradict patterns in other similar studies. This further highlights the need for local data for early diagnosis of pregnancy-associated clinical conditions and management approach.
\end{abstract}

\section{Keywords}

Heamatological Profile, Pregnant Women, Antenatal Clinic, Bauchi, Nigeria 


\section{Introduction}

Pregnancy is characterized by physiological changes that affect the heamostatic status, progress and outcomes [1] [2] [3]. It is influenced by several factors which include socio-cultural and religious practices, genetics, environmental and adherence to antenatal advise [1] [2] [4]. Likewise, haematological profile assessed physiological changes and possible associated clinical complications [1] [2] [5]. Of common haematological abnormalities of pregnancy is anaemia, defined as haemglobin concentration below $11.0 \mathrm{~g} / \mathrm{dl}$ or haemocrit concentration below $33 \%$ according to World Health Organization [6]. In developing countries, particularly in subsaharan Africa including Nigeria, anaemia in pregnancy prevalence is greater than $50 \%$, which varies with geographical location and several factors like infectious disease, malaria and intestinal helminthes that affect haemglobin concentration [7] [8] [9]. Associated clinical complications include high maternal mortality rate, preter maturity, low birth weight, miscarriage and abortion [10] [11] [12]. According to the WHO/UNICEF (1999-2015) joint report on maternal mortality in Nigeria, revealed 58,000 maternal death which accounted for $19 \%$ globally, with the highest maternal mortality rate in the northeastern Nigeria with 1549 death per 100,000 live birth [13].

In pregnancy, physiological characteristics are noticeable with varied haematological levels. Hormonal secretion of oestrogen and progesterone by placenta stimulated release of renin that activates renin-angiotensin mechanism which causes increase in the plasma volume by $40 \%-50 \%$, early in the pregnancy and continued till delivery and sodium retention [1] [14] [15] [16] [17]. While maternal erythropoiesis increases with red cell mass production in response to foetal demand and increased plasma volume results in haemodilutional effect, which is responsible for the decrease in the red blood cell indices [16] [17]. Manifestation of increased haemocrit and haemglobulin concentration decreases with the trimester stages, and typical drop in the second trimester due to maternal plasma volume [2] [5] [18] [19] [20] [21], dependent on factors such as geographical location, malaria, helmthitic infection, dietary and iron supplement intake [22]. While red blood cells indices (MCV, $\mathrm{MCH}$ and $\mathrm{MCHC}$ ) serve as a good indicator of iron-deficiency anaemia in pregnancy and concentration varies with studies [1] [14].

The absolute white blood cell counts increased early in pregnancy and continued throughout the trimesters stages, primarily due to physiological stress, neutrophil count and neutrophilic apoptosis [1] [14] [23] [24]. Neutrophil is a major leucocyte of differential count and contributes significantly to leucocytosis in pregnancy [25] [26] [27]. Gestational thrombocytopenia is second to anaemia of heamatological abnormalities, which occurs in $7 \%-8 \%$ pregnancy, a mild condition that requires no clinical attention [1] [14] [28]. But the decrease in platelets count can be attributable to platelets activation, and clearance [29] [30] [31].

Variability in haematological profile in pregnancy due to several factors as documented in most studies the need for local data derivable from pregnant women attending antenatal clinic to provide important information for clinical 
assessment of pregnancy, wellbeing, and early detection of pregnancy associated complication. Based on this information, we assessed the haematological profile of pregnant women attending antenatal clinic of tertiary hospital in Bauchi State.

\section{Methodology}

The cross-sectional study was conducted at the antenatal clinic of Abubakar Tafawa Balewa University Teaching Hospital, Bauchi between July and August 2018. The 750-bed hospital in Bauchi, North-eastern provides multi medical specialties services to Nigerian and nationals of neighboring countries. The study protocol was approved by ATBUTH instutional review board. Recruitment of study participants was voluntary based on verbal briefing in English and Hausa languages. A well-structure study questionnaire and informed consent were administered by the authors [MAB, LMD, AS] on the study participants after routine antenatal clinical review. Age-matched non-pregnant study participant as control were recruited among member of staff of the hospital with no evidence of pregnancy. Information of the questionnaire includes, age, occupation, residential location, marital status, type of relationship, educational background, gestational age, parity and haematenic intake.

Five millimeter of venous blood specimen was collected aseptically into labeled EDTA bottles for haematological analysis, using Sysmex haematology analyser. The eosinophil, basophil and monocyte were presented as mixed counts.

Haematological profile and demographic variables were analysed using SPSS version20.0, values expressed in mean, frequency and percentages. Categorical variables were compared using chi-square test with statistical significance at $\mathrm{p}<$ 0.05 .

\section{Result}

A total of 191 study participants, comprised of 141 pregnant women at different gestational stages and 50 non pregnant as controls, mean age of $29.26 \pm 5.94$ years. Demographic characteristic of study participant presented in Table 1, majority of study participants were within age-group 27 - 32 years $(\mathrm{n}=76$, $39.79 \%), 52$ (26.18) involved in one business or other, 79 (41.36) had tertiary educational background, 72 (37.70) at second trimester stage 143 (74.87) takes the routine haematenics and 88 (46.08) had multiple parity.

Comparing the haematological profile of pregnant and non-pregnant women as presented in Table 2, significance difference was observed between pregnant and non-pregnant women with mean neutrophil count (0.016), mixed count (0.005), lymphocyte (0.000), platelet (0.002) and RDWSD (0.025). Slightly higher concentration of WBC $(7.7 \pm 5.7)$, neutrophil $(63.7 \pm 8.9), \mathrm{MCV}(86.4 \pm 8.0)$, and low concentration of mixed $(9.4 \pm 5.3)$, lymphocyte $(26.5 \pm 9 \pm 7.4)$, PCV $(35.8 \pm 9.0), \mathrm{Hb}(11.6 \pm 1.6), \mathrm{MCH}(29.2 \pm 3.5)$, MCHC $(33.8 \pm 2.6)$ were recorded among the pregnant compared to non-pregnant women. 
Table 1. Demographic characteristics of pregnant women and control subject.

\begin{tabular}{|c|c|}
\hline Mean Age & $29.26 \pm 5.94$ \\
\hline Variable & Frequency (\%) \\
\hline \multicolumn{2}{|l|}{ Age Group } \\
\hline $15-20$ & $15(7.85)$ \\
\hline $21-26$ & $43(22.51)$ \\
\hline $27-32$ & $76(39.79)$ \\
\hline $33-38$ & $41(21.47)$ \\
\hline$>39$ & $16(8.38)$ \\
\hline \multicolumn{2}{|l|}{ Occupation } \\
\hline Student & $43(22.51)$ \\
\hline Civil Servant & $37(19.37)$ \\
\hline Applicant & $15(7.85)$ \\
\hline Business & $50(26.18)$ \\
\hline Trader & $9(4.71)$ \\
\hline Others & $37(19.37)$ \\
\hline \multicolumn{2}{|l|}{ Residence } \\
\hline Urban & $155(81.20)$ \\
\hline Semi Urban & $34(17.80)$ \\
\hline Rural & $2(1.00)$ \\
\hline \multicolumn{2}{|l|}{ Marital Status } \\
\hline Married & $188(98.43)$ \\
\hline Non-Married & $3(1.57)$ \\
\hline \multicolumn{2}{|c|}{ Type of Relationship } \\
\hline Monogamous & $135(70.68)$ \\
\hline Polygamous & $56(29.32)$ \\
\hline \multicolumn{2}{|l|}{ Educational Status } \\
\hline Islamic & $37(19.37)$ \\
\hline Primary & $19(9.95)$ \\
\hline Secondary & $56(29.32)$ \\
\hline Tertiary & $79(41.36)$ \\
\hline \multicolumn{2}{|l|}{ Gestational Stage } \\
\hline First Trimester & $12(6.28)$ \\
\hline Second Trimester & $72(37.70)$ \\
\hline Third Trimester & $56(29.32)$ \\
\hline Control & $51(26.70)$ \\
\hline \multicolumn{2}{|l|}{ Haematenics } \\
\hline Yes & $143(74.87)$ \\
\hline No & $48(25.13)$ \\
\hline \multicolumn{2}{|l|}{ Parity } \\
\hline Single & $38(19.90)$ \\
\hline Double & $65(34.03)$ \\
\hline Multiple & $88(46.08)$ \\
\hline
\end{tabular}


Comparsion of haematological profile and trimester stage of pregnant women (Table 3), mean haematocrit concentration increased with trimester $(36.4 \pm 3.2)$ at first trimester, a dip at the second trimester $(34.7 \pm 7.1)$, rise at the third trimester $(37.1 \pm 11.5)$, while slight decrease with heamglobulin concentration, $12.3 \pm 1.2,11.6 \pm 1.4$ and $11.3 \pm 2.0$ respectively. $\mathrm{MCV}, \mathrm{MCH}$ and MCHC concentration showed a slightly stable increase from first to third trimester, MCV $83.4 \pm 7.7,86.4 \pm 7.7,87.0 \pm 8.3, \mathrm{MCH}-28.1 \pm 3.3,29.2 \pm 3.0$ and $29.4 \pm 3.1$ and MCHC-33.7 $\pm 2.1,33.8 \pm 3.0$ and $33.8 \pm 2.1$. The mean RDWSD concentration showed increase from $47.6 \pm 3.2$ at the first trimester, drop to $46.5 \pm 6.5$ at second trimester, and rise to $49.0 \pm 9.4$ at the third trimester.

Table 2. Comparison of haematological profile of pregnant and non-pregnant women.

\begin{tabular}{|c|c|c|c|}
\hline Variables & Pregnant women & Non-Pregnant women & P-value \\
\hline PCV & $35.8 \pm 9.0$ & $36.3 \pm 8.9$ & 0.753 \\
\hline $\mathrm{HB}$ & $11.6 \pm 1.6$ & $11.7 \pm 2.2$ & 0.683 \\
\hline WBC & $7.7 \pm 5.7$ & $7.4 \pm 5.6$ & 0.134 \\
\hline NEU & $63.7 \pm 8.9$ & $52.2 \pm 53.9$ & 0016 \\
\hline LYM & $26.9 \pm 7.4$ & $44.7 \pm 14.7$ & 0.0001 \\
\hline MIX & $9.4 \pm 5.3$ & $13.7 \pm 15.7$ & 0.005 \\
\hline PLT & $234.0 \pm 74.6$ & $279 \pm 1.2$ & 0.002 \\
\hline $\mathrm{MCV}$ & $86.4 \pm 8.0$ & $85.4 \pm 6.9$ & 0.449 \\
\hline $\mathrm{MCH}$ & $29.2 \pm 3.5$ & $30.0 \pm 9.6$ & 0.424 \\
\hline $\mathrm{MCHC}$ & $33.8 \pm 2.6$ & $40.0 \pm 45.0$ & 0.104 \\
\hline RDWSD & $47.6 \pm 7.7$ & $62.9 \pm 79.3$ & 0025 \\
\hline
\end{tabular}

Table 3. Comparison of haematological profile with trimester stages.

\begin{tabular}{cccccc}
\hline Variables & Overall mean & 1st Trimester & 2nd Trimester & 3rd Trimester & p-value \\
\hline PCV & $35.8 \pm 9.0$ & $36.4 \pm 3.2$ & $34.7 \pm 7.1$ & $37.1 \pm 11.5$ & 0.313 \\
HB & $11.6 \pm 1.6$ & $12.3 \pm 1.2$ & $11.6 \pm 1.4$ & $11.3 \pm 2.0$ & 0.227 \\
MCV & $86.4 \pm 8.0$ & $83.4 \pm 7.7$ & $86.4 \pm 7.7$ & $87.0 \pm 8.3$ & 0.387 \\
MCH & $29.2 \pm 3.5$ & $28.7 \pm 3.3$ & $29.2 \pm 3.9$ & $29.4 \pm 3.1$ & 0.575 \\
MCHC & $33.8 \pm 2.6$ & $33.7 \pm 2.1$ & $33.8 \pm 3.0$ & $33.8 \pm 2.1$ & 0.973 \\
RDWSD & $47.6 \pm 7.7$ & $47.6 \pm 3.2$ & $46.5 \pm 6.5$ & $49.0 \pm 9.4$ & 0.190 \\
WBC & $7.7 \pm 5.7$ & $13.29 \pm 19.29$ & $7.7 \pm 2.1$ & $6.8 \pm 1.8$ & 0.002 \\
NEU & $63.7 \pm 8.9$ & $60.49 \pm 7.5$ & $65.0 \pm 7.6$ & $62.6 \pm 10.5$ & 0.145 \\
LYM & $26.9 \pm 7.4$ & $31.46 \pm 6.4$ & $26.4 \pm 6.6$ & $26.9 \pm 7.3$ & 0.099 \\
MIX & $9.4 \pm 5.3$ & $8.1 \pm 3.1$ & $8.5 \pm 3.2$ & $10.7 \pm 7.3$ & 0.046 \\
PLT & $234.0 \pm 74.6$ & $270.2 \pm 1.1$ & $231.4 \pm 68.5$ & $230.2 \pm 75.1$ & 0.247 \\
\hline
\end{tabular}


Significant decrease was observed in the mean absolute white cells count with the trimester stages, $13.29 \pm 19.3$ at the first, $7.7 \pm 2.1$ at second and $6.8 \pm 1.8$ at third trimester $(\mathrm{p}<0.002)$. The mean neutrophil count increased with the trimesters, peaked at the second $(65.0 \pm 7.6)$ and drops at third (62.6 \pm 10.5$)$. Significant increase was observed with the mixed counts, from $8.1 \pm 3.1$ at first trimester, $8.5 \pm 3.2$ and $10.7 \pm 7.3$ at third trimester (0.045). Slight decrease in the mean lymphocyte counts was observed, $31.46 \pm 6.4$ to $26.9 \pm 7.3$. Mean Platelet counts demonstrated progressive decrease with trimester, $270.2 \pm 1.1$ at first trimester, $231.4 \pm 68.5$ and $230.2 \pm 75.1$ at third trimester

\section{Discussion}

Haematological profile of pregnant women provides vital information on physiologoical changes associated with pregnancy progress, outcome and maternal-fetal complication [1] [2] [7] [8] [10]. Anaemia is the most common haematological abnormalities that have adverse impact on pregnancy outcome, particularly in developing countries with high maternal mortality [13]. In Nigeria, antenatal care seeking behavior by pregnant women tends to vary with geographical location, ethinic/tribal background, religious belief, educational background, distance from hospital, educational background and economic status [32] [33]. While the haematological profile is associated with genetic background, ethinic/tribal, dietary pattern and parasitic/infectious diseases [22] [34]. As presented on Table 1, the sociodemographic variables of pregnant women like age, parity gestational age, residential location educational background and economic status, were similar with other studies [5] [18] [21] [35] The main findings of our study is the reduction in WBC count and increase in heamocrit concentration, which contradict findings of most similar studies [2] [5] [18] [19] [21] [24]. In addition, overview of our study data, revealed higher haemtological levels than those reported in studies conducted in and outside Nigeria [2] [5] [18] [35] [36], which buttressed the effect of geographical and environmental factors on physiological changes in pregnant women.

In this study, the mean concentration of haemocrit and heamoglobin concentration was slightly lower among pregnant women compared to non-pregnant, with no significant difference, which highlights pregnancy induced physiological changes. However, the mean haemocrit concentration increased with the trimesters, $36.4 \pm 3.2$ recorded at first trimester, with slight dip at the second trimester $34.7 \pm 7.1$ and increase at the third trimester, $37.1 \pm 11.5$ which is at variance with other studies that reported decrease in haemocrit concentration [2] [5] [18] [19] [21] [35] [36]. The observed increase in heamocrit concentration of our study may be due to increase maternal erythropesis as a result of iron demand as pregnancy progresses, fetal growth and increase iron supplement intake [12] [17] [22] [37]. As presented in Table 1, 74.8\% of study participants take haematenics regularly, with no case of anaemia in pregnancy recorded among study participants and low malaria prevalence (2\%) was documented among the 
pregnant women [22]. Typically, reduced mean haemocrit and heamglobin concentrations recorded in the second trimester observed in our study is consistent with other studies [2] [5] [18] [19] [21], which is due to increase plasma volume as reported in most studies. The mean haemoglobin concentration showed a slight decrease with the trimester stages, which is consistent with other studies [2] [5] [18] [19] [21]. As reported in most studies [1] [14] [17], the hormonal secretion of oestrogen and progesterone by placenta cause release of renin which in turn stimulate renin-angiotensin mechanism which triggers increase in plasma volume which range between $40 \%$ - 50\% dependent on the trimester stage, resulting in maternal haemglobin dilution causing physiological anaemia. $\mathrm{MCV}, \mathrm{MCH}$ and $\mathrm{MCHC}$ are red blood cells indices used in the assessment of iron-deficiency anaemia in pregnancy [1] [14]. In this study, the mean MCV and $\mathrm{MCH}$ concentration of $83 \pm 7.7,86.4 \pm 7.7,87.0 \pm 8.3$ and $28.7 \pm 3.3,29.2 \pm 3.9$ and $29.4 \pm 3.1$ revealed a slight increase with the trimesters, while MCHC concentration was stable throughout the trimester stages, similar to other studies but varied with reported concentration [2] [5] [18]. The relatively stable concentration of red blood cells indices as observed in our study could be due to the low prevalence malaria and iron-supplement intake among the pregnant women [22]. In addition, the mean RDWSD level assessed red blood cell width variation, the level increases during pregnancy, and asses iron-deficiency anaemia during pregnancy [2]. In this study, the RDWSD concentration exhibited similar pattern with haemocrit and heamglobin concentration, with increased level at first trimester, slight reduction at second trimester and later increase in the third trimester.

In pregnancy, leucocytosis increases from early stage and continued to the delivery stage, due to series of immunological activities of inflammatory response, selective immune tolerance, immunosuppression and immunomodulation of foetus [19] [23]. This contributes to the slight increase in the mean white blood cells and neutrophil counts among pregnant women compared to non-pregnant women, in contrast to high mean mixed, lymphocyte and platelet counts among non-pregnant women. But significant difference was observed with mean neutrophil (0.015), mixed (0.005) and lymphocyte (0.000) and platelet (0.000). Comparing the mean white blood cell counts with the trimesters, there was significant decrease to the mean absolute white cell count with the trimesters, 13.29 $\pm 19.29,7.7 \pm 2.1$ and $6.8 \pm 1.8(\mathrm{p}<0.002)$. This pattern contradicts the increased WBC count with the trimester stages, as documented in most studies [2] [5] [38], which is attributable to pregnancy induced physiological stress, number of circulating neutrophil and neutrophilic apoptosis [23] [39]. The reduction in WBC count pattern observed in our study was slightly similar to the study conducted in Port Harcourt, Nigeria [35], that reported a relative reduction in WBC count of $9.21 \pm 2.86,9.36 \pm 3.02$ and $9.01 \pm 4.2$. This reduction pattern may be attributable to haemodilutional effect of increased plasma volume.

In normal pregnancy, mean WBC count ranged between 5.7 - 13.6 at the first, 
$5.6-14.8$ and $5.6-16.8$ at the third trimester [40]. The increased WBC counts in pregnancy may not be a good indicator of infection assessment, nevertheless, high WBC count in pregnancy can be a predicator of pregnancy outcome such as preterm delivery, miscarriage, and abortion [41] [42] [43]. Neutrophil is the major leucocyte in differential analysis of WBC count which influenced the absolute WBC count attributable to impaired neutrophil apoptosis [25] [26]. In this study, the mean neutrophil count increased from first trimester 60.49 \pm 8.9 , to $65.0 \pm 7.6$ at the third trimester, with a slight drop to $62.6 \pm 10.5$ at the second trimester, consistent with other studies [2] [5] [18]. In pregnancy, physiological process of oxidative metabolism increased neutrophil count due to activation of neutrophil chemotaxis and phagocytic activity that are depressed by inhibitory factors present in serum of pregnant women [25] [26] [30]. Significant difference was observed in the mean lymphocyte count of pregnant women and non-pregnant women $(\mathrm{p}<0.0001)$. In most studies, mean lymphocytes count decreases with the trimester, which is consistent with our findings that showed a relatively stable decrease with the trimesters, a slight drop at second and increase at third trimester [2] [5] [18] [21].

Eosinophil, monocyte and basophil count response to allergy to intestinal parasitic infection [1]. In this study, eosinophil, basophil and monocyte were presented as mixed counts; significant difference was observed between pregnant women and non-pregnant women, while significant association was observed with the trimesters as reported in similar study conducted in Libya, which revealed relatively decreased mixed counts with the trimester [18]. Primarily, monocyte functions in preventing foetal allograft rejection. While eosinophil and basophil count seem relatively unchanged during pregnancy [1] [14].

The mean platelets count showed a significant difference between pregnant women $(234 \pm 74.6)$ and non-pregnant women $(279 \pm 1.2),(\mathrm{p}<0.002)$. The mean PLT count showed a progressive decreases with the trimester, $270 \pm 1.1$, $231.4 \pm 68.5,230.2 \pm 75.1$ which is consistent with findings of other studies [2] [5] [18] [21]. This decrease in mean platelets count is due to haemodilutional effect of increase in plasma volume, platelet activation and accelerated clearance [25] [26] [27].

\section{Conclusion}

The reduction in the WBC count with trimester and increase haemocrit concentration affirmed the need for more local studies on haematological profiles of pregnancy which is essential to effective monitoring and management during antenatal visits.

\section{Acknowledgements}

We acknowledged the support and assistance of staff of antenatal clinic, department of medical laboratory service and the pregnant women involved in the study towards the completion and success of the study. 


\section{Conflict of Interest}

The authors have collectively reviewed the paper and have no conflict of interest to declare.

\section{References}

[1] Chandra, S., Tripathi, A.K., Mishra, S., Amzarul, M. and Vaish, A.K. (2012) Physiological Changes in Hematological Parameters During Pregnancy. Indian Journal of Hematology and Blood Transfusion, 28, 144-146. https://doi.org/10.1007/s12288-012-0175-6

[2] Purohit, G., Shah, T. and Harsoda, J.M. (2015) Hematological Profile of Normal Pregnant Women in Western India. Scholars Journal of Applied Medical Sciences, 3, 2195-2199.

[3] Harrison, K.A. (1966) Blood Volume Changes in Normal Pregnant Nigerian Women. The Journal of Obstetrics and Gynaecology of the British Commonwealth, 73, 717-723. https://doi.org/10.1111/j.1471-0528.1966.tb06074.x

[4] Yip, R. (2000) Significance of an Abnormally Low or High Hemo-Globin Concentration during Pregnancy: Special Consideration of Iron Nutrition. The American Journal of Clinical Nutrition, 72, 272S-279S. https://doi.org/10.1093/ajcn/72.1.272S

[5] Akinbami, A.A., Ajibola, S.O., Rabiu, K.A., Adewunmi, A.A., Dosunmu, A.O., Adediran, A., Osunkalu, V.O., Osikomaiya, B.I. and Ismail, K.A. (2013) Hematological Profile of Normal Pregnant Women in Lagos, Nigeria. International Journal of Women's Health, 5, 227-232. https://doi.org/10.2147/IJWH.S42110

[6] World Health Organization (1993) Prevention and Management of Severe Anemia in Pregnancy. Report of a Technical Working Group, Geneva, 20-22 May 1991. Maternal Health and Safe Motherhood Programme, WHO, Geneva.

[7] Tolentino, K. and Friedman, J.F. (2007) An Update on Anemia in Less Developed Countries. The American Journal of Tropical Medicine and Hygiene, 77, 44-51. https://doi.org/10.4269/ajtmh.2007.77.44

[8] Olatunbosun, O.A., Abasiattai, A.M., Bassey, E.A., James, R.S., Ibanga, G. and Morgan, A. (2014) Prevalence of Anaemia among Pregnant Women at Booking in the University of Uyo Teaching Hospital, Uyo, Nigeria. BioMed Research International, 2014, Article ID: 849080. https://doi.org/10.1155/2014/849080

[9] Esike, C.O., Anozie, O.B., Onoh, R.C., Sunday, U.C., Nwokpor, O.S. and Umeora, O.U. (2016) The Prevalence of Anemia in Pregnancy at Booking in Abakaliki, Nigeria. Tropical Journal of Obstetrics and Gynaecology, 33, 332-336. https://doi.org/10.4103/0189-5117.199818

[10] Meng, L.Z., Goldenberg, R.L., Cliver, S., Cutter, G. and Blankson, M. (1991) The Relationship between Maternal Hematocrit and Pregnancy Outcome. Obstetrics \& Gynecology, 77, 190-194. https://doi.org/10.1097/00006250-199102000-00005

[11] Allen, L.H. (2000) Anemia and Iron Deficiency: Effects on Pregnancy Outcome. The American Journal of Clinical Nutrition, 71, 1280S-1284S. https://doi.org/10.1093/ajcn/71.5.1280s

[12] Menendez, C., Fleming, A.F. and Alonso, P.L. (2000) Malaria-Related Anaemia. Trends in Parasitology, 16, 469-476. https://doi.org/10.1016/S0169-4758(00)01774-9

[13] World Health Organization (2015) Trends in Maternal Mortality: 1990 to 2015: Estimates by WHO, UNICEF, UNFPA, World Bank Group and the United Nations Population Division. World Health Organization, Geneva. 
[14] Rodríguez-Dennen, F., Martínez-Ocaña, J., Kawa-Karasik, S., Villanueva-Egan, L., Reyes-Paredes, N., Flisser, A. and Olivo-Díaz, A. (2011) Comparison of Hemodynamic, Biochemical and Hematological Parameters of Healthy Pregnant Women in the Third Trimester of Pregnancy and the Active Labor Phase. BMC Pregnancy and Childbirth, 11, Article No. 33. https://doi.org/10.1186/1471-2393-11-33

[15] Soma-Pillay, P., Nelson-Piercy, C., Tolppanen, H. and Mebazaa, A. (2016) Physiological Changes in Pregnancy. Cardiovascular Journal of Africa, 27, 89-94. https://doi.org/10.5830/CVJA-2016-021

[16] Kaur, S., Khan, S. and Nigam, A. (2014) Hematological Profile and Pregnancy: A Review. International Journal of Advances in Medicine, 1, 68-70. https://doi.org/10.5455/2349-3933.ijam20140804

[17] James, T.R., Reid, H.L. and Mullings, A.M. (2008) Are Published Standards for Haematological Indices in Pregnancy Applicable across Populations: An Evaluation in Healthy Pregnant Jamaican Women. BMC Pregnancy and Childbirth, 8, Article No. 8. https://doi.org/10.1186/1471-2393-8-8

[18] Azab, A.E., Albasha, M.O. and Elhemady, S.Y. (2017) Haematological Parameters in Pregnant Women Attended Antenatal Care at Sabratha Teaching Hospital in Northwest, Libya. American Journal of Laboratory Medicine, 2, 60-68. https://doi.org/10.11648/j.ajlm.20170204.14

[19] Osonuga, I.O., Osonuga, O.A., Onadeko, A.A., Osonuga, A. and Osonuga, A.A. (2011) Hematological Profile of Pregnant Women in Southwest of Nigeria. Asian Pacific Journal of Tropical Disease, 1, 232-234.

https://doi.org/10.1016/S2222-1808(11)60036-4

[20] Musa, A.U., Ndakotsu, M.A., Panti, A.A., Shehu, C.E. and Kaoje, A.U. (2016) Haematological Variables of Healthy Pregnant Women in Sokoto, North-Western Nigeria. Sub-Saharan African Journal of Medicine, 3, 194-198.

https://doi.org/10.4103/ssajm.ssajm $41 \quad 16$

[21] Bakrim, S., Motiaa, Y., Ouarour, A. and Masrar, A. (2018) Hematological Parameters of the Blood Count in a Healthy Population of Pregnant Women in the Northwest of Morocco (Tetouan-M'diq-Fnideq Provinces). Pan African Medical Journal, 29, Article 205. https://doi.org/10.11604/pamj.2018.29.205.13043

[22] Kadas, A.S., Okon, K.O., Alkali, M., Jibrin, Y.B., Balogun, S.T., Baffa, M.A., Dattijo, L.M., Shehu, A. and Chama, C. (2019) Low Prevalence of Asymptomatic Malaria in Pregnancy among Subjects Attending AntenatalClinic at a Tertiary Hospital in Bauchi, Nigeria: A Preliminary Report. JAMMR, 29, 1-8.

https://doi.org/10.9734/jammr/2019/v29i430077

[23] Goswami, T.M., Patel, V.N., Pandya, N.H., Mevada, A.K., Desai, K.S. and Solanki, K.B. (2014) Maternal Anaemia during Pregnancy and Its Impact on Perinatal Outcome. International Journal of Biomedical and Advance Research, 5, 99-102. https://doi.org/10.7439/ijbar.v5i2.667

[24] Abass, R.E., Omballi, M.M. and Osman, M.I. (2016) Assessment of Complete Blood Count in Sudanese Pregnant Women in Different Trimesters in Khartoum State. European Academic Research, IV, 5960-5964.

[25] Edlestam, G., Lowbeer, C., Kral, G., et al. (2001) New Reference Values for Routine Blood Samples and Human Neutrophilic Lipocalin during Third Trimester Pregnancy. Scandinavian Journal of Clinical and Laboratory Investigation, 61, 583-592. https://doi.org/10.1080/003655101753267937

[26] Canzoneri, B.J., Lewis, D.F., Groome, L. and Wang, Y. (2009) Increased Neutrophil Numbers Account for Leukocytosis in Women with Preeclampsia. American Jour- 
nal of Perinatology, 26, 729-732. https://doi.org/10.1055/s-0029-1223285

[27] Milman, N., Bergholt, T., Byg, K.-E., Eriksen, L. and Hvas, A.-M. (2007) Reference Intervals for Haematological Variables during Normal Pregnancy and Postpartum in 434 Healthy Danish Women. European Journal of Haematology, 79, 39-46. https://doi.org/10.1111/j.1600-0609.2007.00873.x

[28] Shehlata, N., Burrows, R.F. and Kelton, J.G. (1999) Gestational Thrombocytopenia. Clinical Obstetrics and Gynecology, 42, 327-334. https://doi.org/10.1097/00003081-199906000-00017

[29] McCrae, K.R. (2010) Thrombocytopenia in Pregnancy, American Society of Hematology. Platelet Disorders, 2010, 379-402. https://doi.org/10.1182/asheducation-2010.1.397

[30] Gatti, L., Tinconi, P.M., Guarneri, D., Bertuijessi, C., Ossola, M.W., Bosco, P. and Gianotti, G.A. (1994) Hemostatic Parameters and Platelet Activation by Flow-Cytometry in Normal Pregnancy: A Longitudinal Study. International Journal of Clinical and Laboratory Research, 24, 217-219. https://doi.org/10.1007/BF02592466

[31] Konijnenberg, A., Stokkers, E.W., van der Post, J., et al. (1997) Extensive Platelet Activation in Preeclampsia Compared with Normal Pregnancy: Enhanced Expression of Cell Adhesion Molecules. American Journal of Obstetrics \& Gynecology, 176, 461-469. https://doi.org/10.1016/S0002-9378(97)70516-7

[32] Dahiru, T. and Oche, O.M. (2015) Determinants of Antenatal Care, Institutional Delivery and Postnatal Care Services Utilization in Nigeria. Pan African Medical Journal, 21, Article 321. https://doi.org/10.11604/pamj.2015.21.321.6527

[33] Onyeajam, D.J., Xirasagar, S., Khan, M.M., Hardin, J.W. and Odutolu, O. (2018) Antenatal Care Satisfaction in a Developing Country: A Cross-Sectional Study from Nigeria. BMC Public Health, 18, Article No. 368. https://doi.org/10.1186/s12889-018-5285-0

[34] Smith, G.F. (1993) An Investigation into Some of the Effects of the State of Nutrition of the Mother during Pregnancy and Labour on the Condition of the Child at Birth and for First Few Days of Life. Nutrition, 9, 388-392.

[35] Mba, C.O., Jacob, R.B., Green, M.B. and Zebedee, L.U. (2019) Hematological Profile of Pregnant Women in Port Harcourt, Nigeria. International Journal of Translational Medical Research and Public Health, 3, 1-10. https://doi.org/10.21106/ijtmrph.63

[36] Snehalata, J., Chaudhari, N. and Rajeshri Bodat, K. (2015) Tracking of Heqamatological Parameters in First and Second Trimester Pregnancy. NJMR, 5, 249-261.

[37] Mohamed, A.O., Hamza, K.M. and Babker, A.M. (2016) Physiological Changes in Some Hematological and Coagulation Profile among Sudanese Healthy Pregnant Women. International Journal of Medical Science and Public Health, 5, 525-528.

[38] Gebreweld, A., Bekele, D. and Tsegaye, A. (2018) Hematological Profile of Pregnant Women at St. Paul's Hospital Millennium Medical College, Addis Ababa, Ethiopia. BMC Hematology, 18, Article No. 15. https://doi.org/10.1186/s12878-018-0111-6

[39] Pughikumo, O.C., Pughikumo, D.T. and Omunakwe, H.E. (2015) White Blood Cell Counts in Pregnant Women in Port Harcourt, Nigeria. IOSR-JDMS, 4, 1-3.

[40] Abbassi-Ghanavati, M., Greer, L.G. and Cunningham, F.G. (2006) Pregnancy and Laboratory Studies: A Reference Table for Clinicians. Obstetrics and Gynecology, 114, 1326-1331. https://doi.org/10.1097/AOG.0b013e3181c2bde8

[41] Al-Husban, N., Alhayek, N., Al-Soud, K. and Alhusban, M. (2019) Platelet and White Blood Cell (WBC) Counts in the First Trimester and Pregnancy Outcome: 
Prospective Controlled Study. Journal of Fetal Medicine, 6, 89-94.

https://doi.org/10.1007/s40556-019-00202-0

[42] Lagana, A.S., Favilli, A., Triolo, O., Granese, R. and Gerli, S. (2016) Early Serum Markers of Pre-Eclampsia: Are We Stepping Forward? The Journal of Maternal-Fetal \& Neonatal Medicine, 29, 3019-3023.

https://doi.org/10.3109/14767058.2015.1113522

[43] Toldi, G., Rigó Jr., J., Stenczer, B., Vásárhelyi, B. and Molvarec, A. (2011) Increased Prevalence of IL-17-Producing Peripheral Blood Lymphocytes in Pre-Eclampsia. American Journal of Reproductive Immunology, 66, 223-229.

https://doi.org/10.1111/j.1600-0897.2011.00987.x 